\title{
Defining mainstream literature: the case of energy policy of the European Union ${ }^{1}$
}

\section{Introduction}

— nergy policy of the EU becomes increasingly popular subject among Escientific works related to EU affairs. Specific growth of the scientific literature has been marked during last 20 years. Hence, for scientists it becomes much more difficult to perform one of the fundamental tasks of the research that is defining state of the art within certain subdiscipline.

In order to facilitate fulfilment of this task, one can use search platforms such as ISI Web of Science. It constitutes one of the most important tool of a modern researcher. Using this useful tool makes it possible to discover the broad scope of the publications on the subject. However defining the relative influence of certain publications on the development of science is still a challenge.

In the current literature there are several methods of defining the most influential scientific publications in a certain subdiscipline. However the sustainability of the findings of those searches is still an open issue. The paper addresses this problem by examining two approaches to defining the mainstream literature on a certain topic. In the first case, it verifies the approach of creation of the list of the most influential scientific articles using the "times-cited" and $\mathrm{H}$-index as two of the main criteria. In the second case, the study applies a bibliometric approach by examining 90 academic articles on energy policy of the European Union (EU) published in 2013-2015. The study shows that former approach may lead to unsustainable search results as they are dependent on time when the search was

1 The early version of this article was presented at the workshop of Polish Association of European Studies “Overtaking Crisis: How Can We Do It?", 21 June 2016, in Warsaw. 
completed. The search using bibliometric approach may produce sustainable results as they are not time-dependent. The analysis using the bibliometric approach is further enhanced by making a visualization of cited references' network.

The both approaches use the ISI Web of Science database. The sample includes academic articles in English only. As the latter approach uses the older version of the database, the search is limited to the articles published not later than 2015. The software used for extracting data for bibliometric analysis is Bibjourn.exe. The visualization is generated by the program Ucinet and its application Netdraw.

Sustainability of research results on the mainstream scientific literature depends on application of criteria that are not time-dependent. In light of this theoretical argument throughout this research the following hypotheses will be tested:

Hypothesis 1: application of time-dependent criteria - such as timescited and $\mathrm{H}$-index - will produce unreliable results.

Hypothesis 2: application of permanent criteria - cited references of the same sample of scientific publications - will result in sustainable and thus more reliable findings.

This article is organized along the following lines. First, the brief outline of the dynamics of development of scientific literature on EU energy policy and challenges it poses to scientists, is provided. Second, the method using "times-cited" and H-index is presented. In order to show the time-dependence of this approach the research by Theofanis Exadaktylos i Claudio M. Radaelli ${ }^{2}$ is first analysed and then repeated. The research from 2009 was related to Europeanization topic (and not energy). But since one of the objectives here is to present a method, the topic has only secondary importance and will not undermine the drawn conlusions regarding the pluses and minuses of the approach. Third, the bibliometric approach to defining mainstream literature on EU energy policy is introduced. Fourth, the potential of applying bibliometric approach is revealed by visualtion

2 T. Exadaktylos, C.M. Radaelli, Research Design in European Studies: The Case of Europeanization, "Journal of Common Market Studies" 2009, Vol. 47, Issue 3, p. 515. 
created via program Ucinet and its application Netdraw. And, finally, the main findings of the research are outlined, providing in addition general reflections on applicability of the method in a broader context of an academic work.

\section{The dynamics of development of scientific literature on EU energy policy and challenges it poses to scientists}

Energy policy of the EU becomes increasingly popular subject among scientific works related to EU affairs. Specific growth of the scientific literature has been marked during last 20 years. Figure 1 presents visualization of a growth of the number of scientific publications on that topic.

Figure 1 represents the tendency in science, still it does not ensure complete and precise quantitative data regarding the number of all scientific articles on the energy policy of the EU published during the period mentioned above. It stems from the restrictions embedded in scientific search platform ISI Web of Science as well as criteria applied to the search in the framework of this publication.

First of all, the databases combined within the search platform ISI Web of Science include relatively small number of articles in other languages than English. From 1422 articles on energy policy of the EU found in the ISI Web of Science there are 1321 articles in English, 58 articles are in German, 14 articles are in Polish, 5 articles are in French and Spanish for each language, 4 articles are in Czech and Slovak for each language, 2 articles are in Norwegian and one article is in Finish, Lithuanian and Russian. 14 articles in Polish language represent four scientific journals from Poland - „Rynek energii” (6 articles), „Przegląd Elektrotechniczny” (3 articles), „Rocznik Ochrona Środowiska” (2 articles) oraz "Problems of sustainable development” („Problemy ekorozwoju”, 2 articles). ${ }^{3}$

3 Here the titles of scientific journals are provided in a language versions specified on official websites of respective journals. Thus, only "Problems of sustainable development" has an official translation to English. Other three journals do not have official title version in English and therefore should be written in Polish even in English texts. 
Figure 1. Number of scientific articles on the energy policy of the EU published during the years 1995 - beginning of 2016

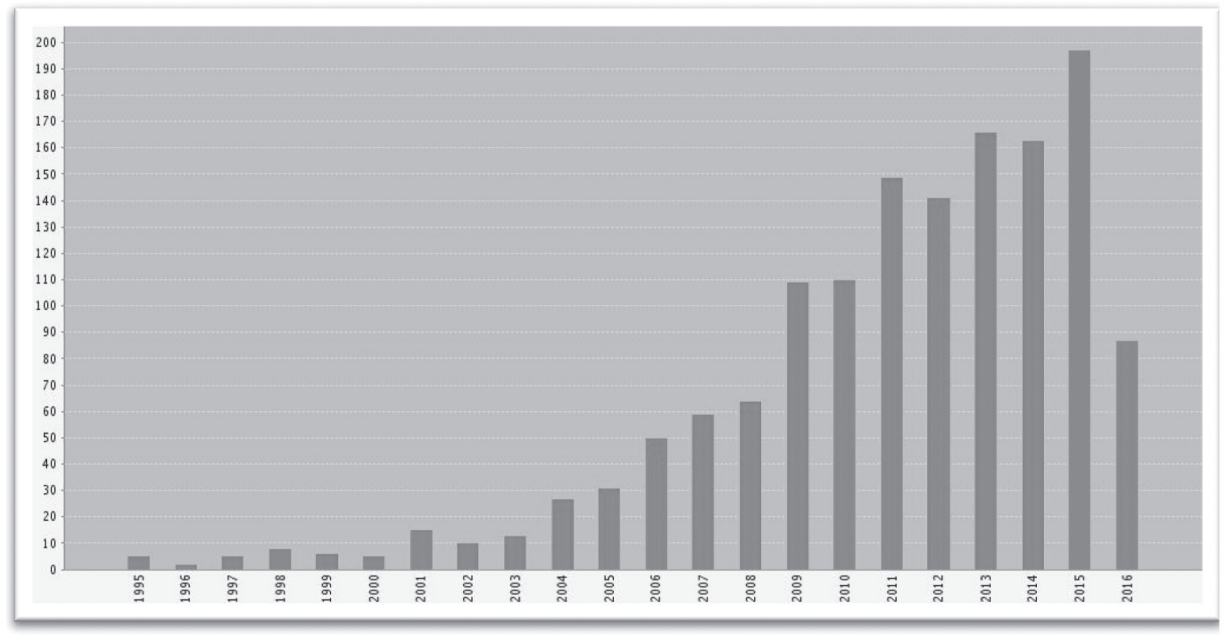

Source: ISI Web of Science; key words “energy policy AND EU”, years 1995-2016, date of access 27 July 2016.

Secondly, as mentioned above, the search was restricted to the articles containing key words "energy policy" and "EU". Therefore the scientific publications focused on detailed research in a narrow technical branch of energy were excluded from the search. Nevertheless, such restrictions do not undermine the credibility of tendency presented in the Figure 1. However, one can make an assumption that the number of literature on energy policy of the EU is much higher than presented in the Figure 1.

One additional note of caution about data presented in Figure 1, however. The search platform provided by Thomson Reuters keep the data constantly updated. Thus the same search performed on different days can produce different results. For example, quantitative data (number of articles) obtained on the $21^{\text {st }}$ April 2016 will differ from search results obtained on the $7^{\text {th }}$ of May 2016. And, although these differences will not affect general conclusions on the growth of the scientific literature on energy topic, it may have an important influence on the findings suggested by qualitative analysis of scientific literature on energy policy of the EU, e.g. literature analysis based on cited references. 
Such a dynamic growth of publications on the subject poses significant challenges for a researcher. First, for a young scientist it should be necessary to provisionally define the area of study. The degree of difficulty of this task depends on a general scope of a certain subject. In case of energy policy of the EU this scope is rather large, because it includes technical spheres (e.g. technological solutions for energy efficiency or extraction of shale gas) as well as political science (e.g. creation of a single energy market of the EU, energy cooperation between EU and third countries). Second component is description of the state of the art in a specific scientific discipline. Each scholar should present an in-depth knowledge of developments within a certain area of study. These challenges can be addressed by defining the mainstream scientific literature on a subject of energy policy of the EU.

\section{Defining mainstream literature using ,times-cited” and $\mathrm{H}$-index criteria}

The H-index (Hirsch index) was first introduced by Jorge E. Hirsch in 2005 in the article titled "An index to quantify an individual's scientific research output" ${ }^{4}$ and since then was broadly used by scientists representing a wide range of scientific disciplines. $\mathrm{H}$-index is used as a tool to characterize the scientific output of a researcher (or a group of researchers). It is based on a calculation of number of papers with citation number $\geq h$. So, basically it applies "times-cited" as a criterion.

One of the examples of the use of $\mathrm{H}$-index is a research made by T. Exadaktylos and C.M. Radaelli ${ }^{5}$ on Europeanization literature. Although it does not relate to energy topic only, this research provides an opportunity to explore one of the methods of defining the mainstream literature. Hence the topic as such has a minor importance in this case, as it allows to draw conclusions on the method.

In addition, the article of T. Exadyktylos i C.M. Radaelli allows to verify the sustainability of the results produced by application of "times-cited" and $\mathrm{H}$-index criteria. The sustainability of the research results means that

4 J.E. Hirsch, An Index to Quantify an Individual's Scientific Research Output, "Proceedings of the National Academy of Sciences of the United States of America" 2005, Vol. 102, Issue 46, pp. 16569-16572.

5 T. Exadaktylos, C.M. Radaelli, op.cit. 
they are not time-dependent. In other words, if the same research can be repeated over time providing the same results, then they can be classified as sustainable and thus reliable. As a result, the verification of the method needs to take an earlier conducted research and repeat it.

In the article T. Exadyktylos and C.M. Radaelli examine the contemporary research design in European integration studies by considering the sub-field of Europeanization. In order to present the list of the most influential literature the authors perform the search of the most cited articles provided by the search platform ISI Web of Science (that time - ISI Web of Knowledge).

In order to perform the analysis T. Exadyktylos and C.M.Radaelli used Social Science Citation Index (SSCI) database that now is available via Web of Science ${ }^{T M}$ Core Collection. Currently this and other databases are combined in the search platform ISI Web of Science. In order to create a sample the authors used key word "Europeani\$ation" and "Politics". They excluded review articles, normative articles without any empirical analysis, industrial relations articles and statistical artefacts. The authors also excluded articles well below the H-index as calculated by the SSCI. This left them with 32 Europeanization articles, cited at least five times. ${ }^{6}$

In order to examine the sustainability of the results mentioned above the research of T. Exadyktylos and C.M. Radaelli was repeated applying similar search criteria. The application of identical criteria was not efficient enough. The use of the same key words that is "Europeani\$ation" and "Politics" returned the search results that did not contain significant number of articles with substantial number of citations, i.a. articles of such prominent and influential scientists as F.W. Scharpf, T.A. Boerzel, H. Grabbe. Therefore key words used in the repeated search were reduced to "Europeani\$ation", leaving out additional key word "Politics". Moreover, the search platform ISI Web of Science is more comprehensive than SSCI used by T. Exadaktylos and C.M. Radaelli. An important element of ISI Web of Science is also advanced search tools that allow to narrow down the search results to scientific articles (excluding i.a. books and reviews). Nevertheless, although with some reservations mentioned above, the repeated research could be continued in order to draw useful scientific conclusions.

6 Ibidem, p. 514. 
Application of the mentioned search criteria resulted in a list of the most frequently cited scientific articles on Europeanization in the years 1997-2007. To put it more clearly, the search criteria did not include the number of citations obtained later than 2007. According to guidelines provided by T. Exadaktylos and C.M. Radaelli the articles from scientific journals "European Journal of Industrial Relations" as well as "British Journal of Industrial Relations" were excluded from the list. The list also excluded articles on the topics not related to political science, namely articles from the "Transactions of the Institute of British Geographers" and "Higher Education". In addition, the final search result excluded articles well below the $\mathrm{H}$-index that did not appear in the list of T. Exadaktylos and C.M. Radaelli. Furthermore, the new list of the most frequently cited articles included the articles that had the largest number of citations but did not appear in an article from 2008 and were not below $\mathrm{H}$-index calculated by ISI Web of Science on 8 May 2016. The last position was the same as in search results from 2008. The comparison of two search results are presented in Table 1.

Data presented in Table 1 show that the search based on the similar criteria but performed on different dates, produces different lists of the most frequently cited articles on Europeanization. The list from 2008 includes 32 positions, however the final list from 2016 has 47 positions, although the articles not related to political science were removed from the list.

Based on Table 1 one can conclude, that the number of citations for the same positions differs depending on the date the search was performed. The only one exception is an article of M.Lodge from 2000 that in the both lists has the same number of citations (5). The difference in number of citations is from 1 to 25 in case of publications appearing in the both lists (i.e. in 2008 and 2016) and from 5 to 43 in case of positions included only in the search from 2016.

More interesting findings emerge from results of comparison of the two lists of the most frequently cited articles on Europeanization from 2008 and 2016. Since the average number of citations for the sample from 8 May 2016 is 19.79 , the analysis will focus on scientific publications that have 20 and more citations. As a result, the list under consideration contains 19 scientific articles. 
Examination of 19 the most frequently cited articles according to search results from 8 May 2016 shows that six authors M. Jachtenfuchs, S. Mazey, W. Wessels, J. Richardson, K.H. Goetz and C. Knill do not appear in the search results from 1 February 2008, although according to the latest search they have high number of citations - 43, 39, 31, 27, 26 and 24 respectively. The highest number of citations in the search results from February 2008 is 39. Ten from nineteen positions in the search results from 2016 appear also in the top ten of the most frequently cited articles from 2008. Three positions do not appear in the search results from 2008. Nevertheless from 32 positions of the newest search they took $13^{\text {th }}, 18^{\text {th }}$ and $22^{\text {nd }}$ place.

Table 1. Number of the most frequently cited scientific articles on Europeanization in 1997-2007: comparison of search results from 1 February 2008 and 8 May 2016

\begin{tabular}{|c|c|c|c|c|c|c|c|}
\hline No. & Authors & Journal & $\begin{array}{l}\text { Publ. } \\
\text { Year }\end{array}$ & 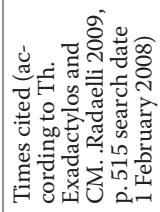 &  & 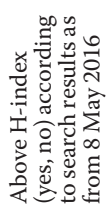 & 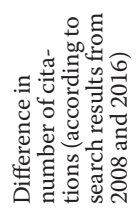 \\
\hline 1 & Scharpf FW & JEPP & 1997 & 39 & 47 & yes & 8 \\
\hline 2 & Borzei TA & JCMS & 1999 & 38 & 45 & yes & 7 \\
\hline 3 & Grabbe H & JEPP & 2001 & 31 & 56 & yes & 25 \\
\hline 4 & Benz and Eberlein & JEPP & 1999 & 29 & 32 & yes & 3 \\
\hline 5 & Knill and Lehmkuhl & EJPR & 2002 & 26 & 40 & yes & 14 \\
\hline 6 & Borzei TA & JCMS & 2002 & 21 & 38 & yes & 17 \\
\hline 7 & Harmsen R & Governance & 1999 & 17 & 22 & yes & 5 \\
\hline 8 & Marcussen et al. & JEPP & 1999 & 18 & 29 & yes & 11 \\
\hline 9 & Lippert; Umbach; Wessels & JEPP & 2001 & 17 & 22 & yes & 5 \\
\hline 10 & Cole and Drake & JEPP & 2000 & 15 & 20 & no & 5 \\
\hline 11 & Agh A & JEPP & 1999 & 13 & 15 & no & 2 \\
\hline 12 & Bursens P & Scandinavian Pol Stud & 2002 & 13 & 18 & no & 5 \\
\hline 13 & Lavenex S & JCMS & 2001 & 13 & 24 & yes & 11 \\
\hline 14 & Schmidt VA & JEPP & 2002 & 13 & 15 & yes & 2 \\
\hline 15 & Andersen MS & Am Beh Scientis & 2002 & 12 & 13 & no & 1 \\
\hline 16 & Gilardi F & $\begin{array}{l}\text { Annals of Am Ac of } \\
\text { Pol Soc Sa }\end{array}$ & 2005 & 12 & 18 & yes & 6 \\
\hline 17 & Radaelli CM & CPS & 1997 & 12 & 17 & no & 5 \\
\hline 18 & Dimitrova & WEP & 2002 & 11 & 21 & yes & 10 \\
\hline 19 & Dyson K & JCMS & 2000 & 11 & 14 & no & 3 \\
\hline 20 & Semetko; de Vreese; Peter & WEP & 2000 & 11 & 15 & no & 4 \\
\hline
\end{tabular}


Continuation of Table 1

\begin{tabular}{|c|c|c|c|c|c|c|c|}
\hline 21 & Levi-Faur D & CPS & 2004 & 10 & 14 & yes & 4 \\
\hline 22 & $\begin{array}{l}\text { Schimmelfennig } \\
\text { and Sedelmeier }\end{array}$ & JEPP & 2004 & 9 & 24 & yes & 15 \\
\hline 23 & Ladrech R & PARTY POLITICS & 2002 & 8 & 19 & yes & 11 \\
\hline 24 & Eyre and Lodge & JEPP & 2000 & 7 & 13 & no & 6 \\
\hline 25 & Falkner G & JCMS & 2000 & 7 & 10 & no & 3 \\
\hline 26 & Cole A & JCMS & 2001 & 6 & 9 & no & 3 \\
\hline 27 & Warleigh A & JCMS & 2001 & 6 & 18 & yes & 12 \\
\hline 28 & Anderson JJ & JCMS & 2002 & 5 & 9 & no & 4 \\
\hline 29 & Severs and Trondal & WEP & 2004 & 5 & 8 & no & 3 \\
\hline 30 & Fischer; Nicolet; Sciarini & WEP & 2002 & 5 & 11 & no & 6 \\
\hline 31 & Lodge M & WEP & 2000 & 5 & 5 & no & 0 \\
\hline 32 & Smtth J & PA & 2001 & 5 & 6 & no & 1 \\
\hline 33 & Jachtenfuchs M & JCMS & 2001 & 0 & 43 & yes & 43 \\
\hline 34 & Mazey S & JEPP & 1998 & 0 & 39 & yes & 39 \\
\hline 35 & Wessels W & JEPP & 1998 & 0 & 31 & yes & 31 \\
\hline 36 & Richardson J & Poi Stud & 2000 & 0 & 27 & yes & 27 \\
\hline 37 & Goetz KH & JEPP & 2001 & 0 & 26 & yes & 26 \\
\hline 38 & Knill C & JEPP & 2005 & 0 & 24 & yes & 24 \\
\hline 39 & Holzinger and Knill & JEPP & 2005 & 0 & 19 & yes & 19 \\
\hline 40 & Goetz KH & WEP & 2000 & 0 & 15 & yes & 15 \\
\hline 41 & Schmidt and Radaelli & WEP & 2004 & 0 & 13 & yes & 13 \\
\hline 42 & Eberlein and Grande & JEPP & 2005 & 0 & 10 & yes & 10 \\
\hline 43 & Mastenbroek E & JEPP & 2005 & 0 & 8 & yes & 8 \\
\hline 44 & Webber et al. & $\begin{array}{l}\text { REVIEW OF } \\
\text { INTERNATIONAL } \\
\text { STUDIES }\end{array}$ & 2004 & 0 & 7 & yes & 7 \\
\hline 45 & Lopez-Santana M & JEPP & 2006 & 0 & 6 & yes & 6 \\
\hline 46 & Bruno; Jacquot; Mandin & JEPP & 2006 & 0 & 6 & yes & 6 \\
\hline 47 & Risse $\mathrm{T}$ & JEPP & 2005 & 0 & 5 & yes & 5 \\
\hline
\end{tabular}

Source: Author's own data based on ISI Web of Science platform search results from 1 February 2008 (in the article of T. Exadaktylos i C.M. Radaelli mentioned above) and 8 May 2016. Abbreviations: JEPP - Journal of European Public Policy, JCMS Journal of Common Market Studies, EJPR - European Journal of Political Research, Governance - Governance - An International Journal of Policy and Administration, Scandinavian Pol Stud - Scandinavian Political Studies, Am Beh Scientis - American Behavioral Scientist, Annals of Am Ac of Pol Soc Sci-Annals Of The American Academy Of Political And Social Science, CPS - Comparative Political Studies, WEP - West European Politics, PA - Public Administration, Pol Stud - Political Studies, H-index - Hirsch index.

The search made in 2016 returned the list of 28 authors with citation number lesser than 20. Nine out of twenty eight positions do not appear 
on the list of the most frequently cited articles from 2008, although the number of citations they have is higher than the least cited article in the list of T. Exadaktylos and C.M. Radaelli. In these cases the highest number of citations is 19 (same as R. Ladrech that appears in search results from 2008), but the smallest number of citations is 5 (same as M. Lodge that appears in search results from 2008).

To sum it up, the complete list of the most frequently cited articles on Europeanization created on 8 May 2016 includes 15 new positions with the high number of citations. The majority of articles in the completed version of the list was published in 2005 (5 articles), and two articles appeared in 1998, 2000, 2001, 2004 and 2006. From the newest list of the most frequently cited articles substantial part of articles was published in "Journal of European Public Policy" (JEPP) (10 articles), two new articles were published in the "West European Politics" (WEP) and one article in each of the following journals - "Journal of Common Market Studies" (JCMS), "Political Studies" and "Review of International Relations". In other words, the completed list reiterates the dominance of JEPP during 1997-2007, because the number of articles from this journal increased two times. The same conclusion on the influence can be drawn regarding the JCMS and WEP. Two new journals appeared in the list - Political Studies and Review of International Relations.

The findings presented above prove significant difference in search results in 2008 and 2016, although the search was conducted using the similar criteria and, what is more important, the same time period - from 1997 till 2007. Such a difference was caused mainly by the criteria applied by T.Exadaktylos and C.M. Radaelli, namely "times-cited" and the level of $\mathrm{H}$-index. As mentioned above, the authors excluded all articles well below the level of $\mathrm{H}$-index ${ }^{7}$.

In the Thomson Reuters database the level of Hirsch index for certain number of scientific articles is calculated in similar manner as for one author. The advantage of h-index in this case is that in addition to the whole scope of related articles it reflects also the number of cited articles. However, the disadvantage of h-index is that it changes constantly over time, because of constant updating of information included in ISI Web of Science database. In other words, h-index is not a permanent indicator. As a result,

\footnotetext{
7 Ibidem, p. 514.
} 
the search performed over time applying the identical criteria may return different level of h-index for the scope of the most frequently cited scientific literature. The larger is a time gap between the searches, the higher the probability of difference in the level of h-index in each search. Most probably the h-index will be different and thus incomparable.

As a result, the application of "times-cited" and h-index as criteria leads to imprecise conclusions regarding the most frequently cited articles in 1997-2007. During this period, as Table 1 shows, 15 articles were de facto more influential in area of Europeanization study than suggested by T. Exadaktylos and C.M. Radaelli. In addition, the other 15 articles were less influential than it was supposed in the research from 2008.

These findings can be applied also in different areas of studies, e.g. energy policy of the EU. Application of the same time-dependent criteria in order to define the mainstream literature will produce same problematic results. However, it is reasonable to assume that the sustainability of $\mathrm{H}$-index may have minor importance in the disciplines with not so dynamic growth of scientific literature as in case of Europeanization or EU energy policy. This assumption can be tested in future research of application of $\mathrm{H}$-index. However, this section of the article proves that application of this criteria is not suitable for broad scientific subdisciplines. Therefore, the next chapter will focus on another approach in defining mainstream literature.

\section{Defining mainstream literature using bibliometric approach}

In this section the mainstream academic literature will be defined using bibliometric approach. One of the most appropriate database for fulfilling this task is the older version of Social Science Citation Index (SSCI) that can be accessed through the older version of ISI Web of Science, i.e. Web of Science ${ }^{T M}$ Core Collection. This database allows retrieving bibliometric data from the sample of scientific articles and their conversion to the $\mathrm{Mi}$ crosoft Excel for a later use.

The sample of scientific articles on the EU Energy policy was created using the following key words - "energy policy" AND "EU". In order to facilitate later comparison of two methods of defining the mainstream academic literature the sample included exclusively scientific articles (thus 
excluding other types of publications) in English. The sample included the scientific articles published in 2013-2015 (three full years).

The use of the aforementioned criteria created a sample of 90 academic articles published in the timespan mentioned above. The program used to retrieve bibliometric data was Bibjourn.exe. The further procedure ran according to the instructions available on the internet blog of Professor Loet Leydesdorff from the University of Amsterdam. ${ }^{8}$ The files generated by the program Bibljourn.exe were later used in Microsoft Excel. Consecutive use of both programs created a list of 1883 cited references. Further data processing procedure included, first, creation of the list of scientific sources cited two or more times throughout 90 articles of the sample and, second, creation of visualization of academic publications' network. The fulfilment of the first objective gave the opportunity to create a binary matrix containing the most cited articles as rows and the 90 articles of the sample as columns. The articles in the sample were named $n 1, n 2, n 3, \ldots$, n90. The value of the academic source was " 1 " if it was cited in the respective academic article of the sample, and the value was " 0 " if it was not cited. The matrix was later used for visualization purpose in the program Ucinet and its application Netdraw.

The final list of the most influential scientific sources included only unique cited references, i.e. the repeated cited references (duplicates) in one article were ignored. Thus the list contained 134 positions cited two or more times throughout 90 academic articles of the sample. Throughout 90 articles of the sample 1 academic source was cited 6 times, 2 sources were cited 5 times, 3 sources were cited 4 times, 22 sources were cited 3 times and 107 sources were cited 2 times.

In order to make visualization of further matrix the list of most cited academic sources had to be reduced. The method used for reduction was created by calculating a mean value for the cited references and applying it as a limit. In this case the following formula was applied:

$$
\bar{X}=\frac{6 \times 1+5 \times 2+4 \times 2+3 \times 22+2 \times 107}{134} \approx 2,27
$$

8 L. Leyedesdorff, BibJourn.exe for Cocitation Analysis of Journal Names in References, http://www.leydesdorff.net/software/bibjourn/ [accessed: 14.06.2016]. 
Thus the visualization included only those academic sources that was cited 3 or more times, 27 positions in total. The summary of the final list is presented in Table 2.

The first quick qualitative look at the Table 2 shows that the most cited works belong to Patrik Thollander. From 4 of 27 academic sources belong to this author. Reinhard Haas is the author of 2 academic sources out of 27. Regarding the academic sources on the top of it is an academic journal "Energy Policy", taking 12 positions out of 27 followed by "Energy" and "Renewable and Sustainable Energy Reviews", taking 2 positions each. It is remarkable that the non-journal sources are in clear minority. Furthermore the majority of academic sources was published in 2006-2012 (on average 3 sources per year).

Table 2. The list of the mainstream academic literature in the years 2013-2015

\begin{tabular}{|c|c|c|c|}
\hline Author & Journal/Source & Year & Times cited" \\
\hline TINBERGEN J & THEORYECPOLICY & 1952 & 5 \\
\hline SORRELL S & REDUCINGBARRIERSEN & 2000 & 3 \\
\hline MENANTEAU P & ENERGPOLICY & 2003 & 3 \\
\hline "EC & COM2006545EC & 2006 & 3 \\
\hline MITCHELL C & ENERGPOLICY & 2006 & 5 \\
\hline CORRELJE A & ENERGPOLICY & 2006 & 3 \\
\hline "EURCOMM & COM20071EURCOMM & 2007 & 3 \\
\hline THOLLANDER P & ENERGPOLICY & 2007 & 4 \\
\hline ROHDIN P & ENERGPOLICY & 2007 & 3 \\
\hline THOLLANDER P & ENERGEFFIC & 2008 & 3 \\
\hline FINON D & ENERGPOLICY & 2008 & 3 \\
\hline STREIMIKIENE D & ENVIRONINT & 2008 & 3 \\
\hline JACOBSSON S & ENERGPOLICY & 2009 & 3 \\
\hline POINTVOGL A & ENERGPOLICY & 2009 & 3 \\
\hline YOUNGS R & ENERGYSECURITYEURO & 2009 & 3 \\
\hline PIRANI S & RUSSOUKRAINIANGAS & 2009 & 3 \\
\hline TILMAN D & SCIENCE & 2009 & 3 \\
\hline FANKHAUSER S & CLIMATECHANGEEC & 2010 & 3 \\
\hline \begin{tabular}{|l|} 
THOLLANDER P \\
\end{tabular} & ENERGY & 2010 & 3 \\
\hline THOLLANDER P & JCLEANPROD & 2010 & 4 \\
\hline KLESSMANN C & ENERGPOLICY & 2011 & 3 \\
\hline HAAS R & ENERGY & 2011 & 3 \\
\hline HAAS R & RENEWSUSTENERGREV & 2011 & 6 \\
\hline FLEITER T & RENEWSUSTENERGREV & 2011 & 3 \\
\hline BACKLUND S & ENERGPOLICY & 2012 & 3 \\
\hline
\end{tabular}


Continuation of Table 2

\begin{tabular}{|l|l|l|l|}
\hline DELRIO P & ENERGPOLICY & 2012 & 3 \\
\hline KITZING L & ENERGPOLICY & 2012 & 3 \\
\hline
\end{tabular}

* Times cited in a sample of 90 scientific articles.

Source: Author's own data.

For this and future research there is one important remark. Although the main list containing 27 positions is more transparent, the full list comprising 134 should not be ignored in qualitative analysis. The full list might be further needed, first, to define the most influential scientists and, second, to describe some parts of the visualization in a more detailed manner. In the former case if the main list contains certain author, it could be important to check, how often the certain author appears in a full list in order to describe his or her relative influence during the years 2013-2015. For instance, in the main list of the most cited academic sources an author Catherine Mitchel appeared once on the second place with the article „Effectiveness through risk reduction: a comparison of the renewable obligation in England and Wales and the feed-in system in Germany" (times cited $=5$ ). However in the full list Catherin Mitchel appeared two times. The second position of this author, that was cited two times, was „Renewable energy policy in the UK 1990-2003”. Such an analysis of authors allows to draw more precise conclusions regarding the impact of certain author on the development of a certain subdiscipline.

To sum up, the main and the full list present the mainstream literature that had a significant impact on development of research on EU energy policy in 2013-2015. This list will not change through time as will not change the bibliometric parameters of the 90 articles in the sample. However it should be underlined that the both lists present only mainstream literature. General conclusions should be drawn carefully, with some significant restrictions. First, as mentioned above, the fact that a certain author appears only once in a top 27 list does not mean that the same author will not be mentioned repeatedly in a full list of academic sources (comprising 134 articles). Thus the influence of such an author should not be underestimated. Second, neither main list, nor full list do not show division of authors across subtopics of EU energy policy. For instance, R. Haas and P. Thollander write 
about different topics in the framework of EU energy policy. Hence, their importance cannot be even compared in general terms. Third, the codification of an academic source that has multiple authors, include only the first author. That means that some of the authors that appear in a top 27 can be also co-authors of other publications that appear in the same list, but can be hidden under codification. This, again, proves that the general conclusions on the impact of an author should be drawn very carefully.

The aforementioned conclusions prove that the list of the academic sources, although visually attractive and clear, is not the final stage of the research of a mainstream literature. The way to overcome the aforementioned restrictions is the creation of a visualization of network of scientific works included in the top 27 articles and the list of 90 articles of the sample. Further analysis of the visualization will reveal potential of the bibliometric approach and will help to draw more precise and comprehensive conclusions on the mainstream literature.

\section{Construction and analysis of visualization using data from bibliometric data}

The bibliometric analysis of 90 sample articles on EU energy policy was further used for visualization purposes in the program Ucinet and its application Netdraw. ${ }^{9}$ For this research the 6.614 version of Ucinet was used. The objective of the use of this program actually was to convert the Microsoft Excell file with the matrix into the file suitable for the Netdraw (with the extension.\#\#h instead of .xls). The consequent visualizations were generated in a Graph theoretic layout in Netdraw. In order to improve the transparency of the visualization the position of some of its components was slightly changed. This small adaptation however did not bring any significant changes to the overall visualization.

The matrix created by procedures mentioned in a previous section of this paper produced a visualization that is presented in a Figure 2. With-

9 Netdraw is an application of the program Ucinet. It can be installed together with Ucinet as its application (in this case only Ucinet is installed) or as a separate program Netdraw (in this case installation is performed separately for Ucinet and for Netdraw). It should be noted however, when installed separately, Netdraw might not function properly within Ucinet. In this case Netdraw should be used separately and not as Ucinet application. 
out a detailed analysis it can be concluded that the literature on EU energy policy is divided into two separate networks. Larger network has one epicentre, i.e. concentration of visualization components in the middle of a figure as well as two clearly visible smaller branches. In order to clarify the reasons of such a location the visualization components as well as their connections were further analysed in details.

The separate network (in the top left part of the Figure 2) connects publications whose authors of co-authors are P. Thollander, Patrik Rohdin, Sandra Backlund, Tobias Fleiter, Steve Sorrell as well as European Commission. As it was mentioned in a previous section of this paper, the code of the most cited academic source comprises only one author even in case of group authorship. The full list of the authors of a certain academic source can be found in a footnote. For the purpose of this paper only those additional authors will be mentioned who has "own" position on the top 27 list. Such an example is P. Rohdin that has its "own" position in the main list (the top 27) and appears as a co-author in one of the articles of P. Thollander. Moreover P. Thollander is a co-author of an article of S. Backlund and P. Rohdin. It cannot be seen in the Figure 2, therefore in-depth analysis of each position can bring more useful information that will help to define the most influent authors.

Figure 2. Visualization of networks of the most cited academic sources in 2013$-2015$

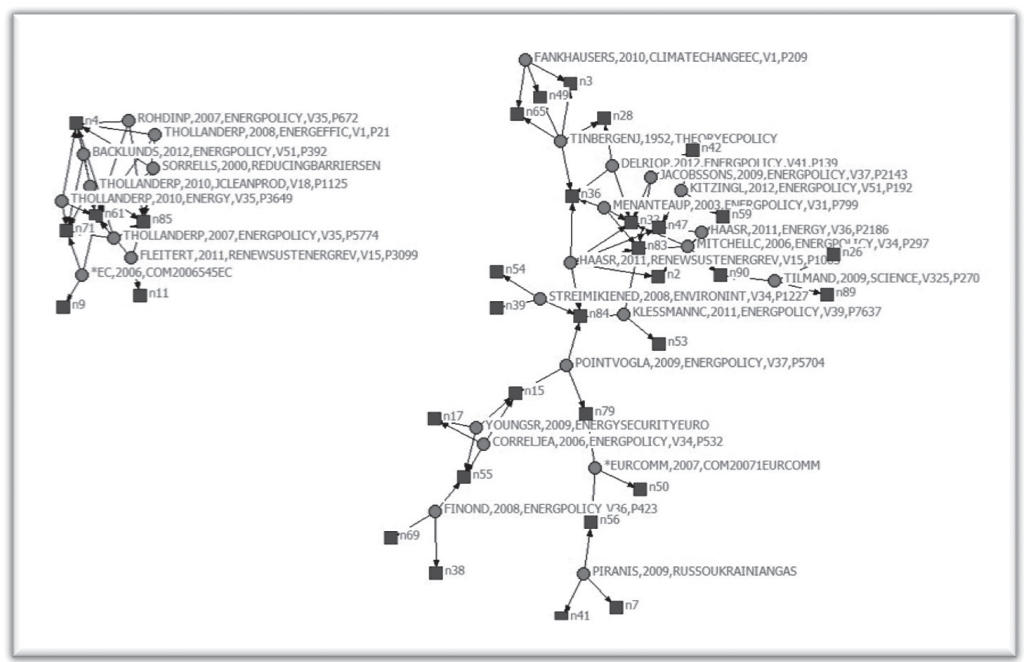


Source: Author's own data.

The separate network in the right part of a Figure 2 includes four articles of P.Thollander's authorship on the subject of energy efficiency. These are articles „An energy efficient Swedish pulp and paper industry - exploring barriers to and driving forces for cost-effective energy efficiency investments", 10 "Energy management practices in Swedish energy-intensive industries",11 "Analyzing variables for district heating collaborations between energy utilities and industries"12 as well as "Energy policies for increased industrial energy efficiency: Evaluation of a local energy programme for manufacturing SMEs" ${ }^{13}$ Connected to this network is also an article of P. Rohdin et al. „Barriers to and drivers for energy efficiency in the Swedish foundry industry", ${ }^{14}$ a scientific article S. Backlund et al. "Extending the energy efficiency gap", ${ }^{15}$ scientific article of T. Fleitert et al. "Barriers to energy efficiency in industrial bottom-up energy demand models - a review"16, final report of S. Sorrel et al. funded by the European Commission (EC) „Reducing barriers to energy efficiency in public and private organisations"17 as well as communication from the EC entitled "Action Plan for Energy Efficiency: Realising the Potential". 18 The common

10 P. Thollander, M. Ottosson, An Energy Efficient Swedish Pulp and Paper Industry - Exploring Barriers to and Driving Forces for Cost-effective Energy Efficiency Investments, "Energy Efficiency" 2008, Vol. 1, Issue 1, pp. 21-34.

11 P. Thollander, M. Ottosson, Energy Management Practices in Swedish Energy-intensive Industries, "Journal of Cleaner Production" 2010, Vol. 18, Issue 12, pp. 1125 -1133.

12 P. Thollander, I.L. Svensson, L. Trygg, Analyzing Variables for District Heating Collaborations Between Energy Utilities and Industries, "Energy" 2010, Vol. 35, Issue 9, pp. 3649-3656.

13 P. Thollander, M. Danestig, P. Rohdin, Energy Policies for Increased Industrial Energy Efficiency: Evaluation of a Local Energy Programme for Manufacturing SMEs, "Energy Policy" 2007, Vol. 25, Issue 11, pp. 5574-5583.

14 P. Rohdin, P. Thollander, P. Solding, Barriers to and Drivers for Energy Efficiency in the Swedish Foundry Industry, "Energy Policy" 2007, Vol. 35, Issue 1, pp. 672-677.

15 S. Backlund, P. Thollander, J. Palm, M. Ottosson, Extending the Energy Efficiency Gap, “Energy Policy” 2012, Vol. 51, pp. 392-396.

16 T. Fleiter, E. Worrell, W. Eichhammer, Barriers to Energy Efficiency in Industrial Bottom-up Energy Demand Models - a Review, "Renewable and Sustainable Energy Reviews" 2011, Vol. 15, Issue 6, pp. 3099-3111.

17 S. Sorrell et al., Reducing barriers to energy efficiency in public and private organizations, [in:] Science and Policy Technology Research (SPRU), Sussex 2000.

18 European Commission, Action Plan for Energy Efficiency - Realising the Potential, http:// eur-lex.europa.eu/legal-content/EN/TXT/HTML/?uri=CELEX:52006DC0545\&from=EN [accessed: 24.07.2016]. 
aspect connecting all these academic sources is the topic of energy efficiency. Thus it can be concluded, that the literature on energy efficiency is separated from the broad scope of research on EU energy policy.

The largest network is characterized by concentration of the majority visualization components in the top middle part of the Figure 2 with several branches. The core of the network is formed by scientific publications of such authors as R. Haas, Catherine Mitchell, Lena Kitzing, Staffan Jacobsson, Pablo del Rio, Philippe Menanteau and David Tilman. R. Haas appears also as co-author of an article of L. Kitzing. Besides two articles of $R$. Haas were prepared by virtually the same group of authors (see references). Some of the members of this group of authors - Anne Held and Mario Ragwitz - appear also among the co-authors of an article of Corinna Klessmann that is discussed further.

The majority of connections (citations) that places the respective position in the centre of analysed network has an article of R. Haas et al. „A historical review of promotion strategies for electricity from renewable energy sources in EU countries". ${ }^{19}$ Within this network there is one more article of this author - „Efficiency and effectiveness of promotion systems for electricity generation from renewable energy sources - Lessons from EU countries" ${ }^{20}$ These two articles are connected with an article of C. Mitchell et al. „Effectiveness through risk reduction: a comparison of the renewable obligation in England and Wales and the feed-in system in Germany".21

In the core of those connections there is also an article of L. Kitzing et al. „Renewable energy policies in Europe: Converging or diverging?”, 22 an article of S. Jacobsson et al. "EU renewable energy support policy: Faith or

19 R. Haas, C. Panzer, G. Resch, M. Ragwitz, G. Reece, A. Held, A Historical Review of Promotion Strategies for Electricity from Renewable Energy Sources in EU Countries, "Renewable and Sustainable Energy Reviews" 2011, Vol. 15, Issue 2, pp. 1003-1034.

20 R. Haas, G. Resch, C. Panzer, S. Busch, M. Ragwitz, A. Held, Efficiency and effectiveness of promotion systems for electricity generation from renewable energy sources - Lessons from EU countries, "Energy" 2011, Vol. 36, Issue 4, pp. 2186-2193.

21 C. Mitchell, D. Bauknecht, P. Connor, Effectiveness through Risk Reduction: A Comparison of the Renewable Obligation in England and Wales and the Feed-in System in Germany, "Energy Policy" 2006, Vol. 34, Issue 3, pp. 297-305.

22 L. Kitzing, C. Mitchell, P.E. Morthorst, Renewable Energy Policies in Europe: Converging or Diverging, "Energy Policy" 2012, Vol. 51, pp. 192-201. 
facts?", ${ }^{23}$ an article of P. del Rio "The dynamic efficiency of feed-in tariffs: The impact of different design elements", ${ }^{24}$ and an article of P. Menanteau et al. "Prices versus quantities: choosing policies for promoting the development of renewable energy". ${ }^{25}$ The common feature of all those articles is that they all refer to the topic of renewable sources of energy. One of the smaller branches is formed by a response to a comment in the scientific magazine Science written by David Tilman et al. „Biofuels: Steer Clear of Degraded Land - Response". ${ }^{26}$ This publication also refers to the renewables, but reflects on a particular issue of the study field - biofuels. Therefore on the Figure 2 it creates a small branch that is situated not far from the cluster of connections.

The next connection to the top of the core is formed by a book of Jan Tinbergen „On the Theory of Economic Policy”. ${ }^{27}$ On the one side, this component is connected to the academic sources that refer to the renewable sources of energy. On the other side, it is closely related to an article of Samuel Fankhauser et al. „Combining Multiple Climate Policy Instruments: How Not To Do It" ${ }^{28}$ about climate change policy and economics of climate change mitigation. Thus the conclusion can be drawn, that the economic aspects of energy policy is somewhat distinct from the broad scope of the literature on the energy policy.

Next branch is formed by an article of Dalia Streimikiene et al. „The EU sustainable energy policy indicators framework" 29 and Corinna Klessmann et al. "Status and perspectives of renewable energy policy and deployment

23 S. Jacobsson, A. Bergek, D. Finon, V. Lauber, C. Mitchell, D. Toke, A. Verbruggen, EU renewable energy support policy: Faith or facts?, "Energy policy" 2009, Vol. 37, Issue 6, pp. 2143$-2146$.

24 P. Del Río, The dynamic efficiency of feed-in tariffs: The impact of different design elements, "Energy Policy" 2012, Vol. 41, pp. 139-151.

25 P. Menanteau, D. Finon, M.L. Lamy, Prices versus quantities: choosing policies for promoting the development of renewable energy, "Energy Policy" 2003, Vol. 31, Issue 8, pp. 799-812.

26 D. Tilman, R. Socolow, J.A. Foley, J. Hill, E. Larson, L. Lynd, S. Pacala, J. Reilly, T. Searchinger, C. Somerville, R. Williams, Biofuels: steer clear of degraded land response, "Science" 2009, Vol. 325, Issue 5938, pp.270-271.

27 J. Tinbergen, On the Theory of Economic Policy, Amsterdam 1952.

28 S. Fankhauser, C. Hepburn, J. Park, Combining multiple climate policy instruments: how not to do it, "Climate Change Economics" 2010, Vol. 1, Issue 3, pp. 209-225.

29 D. Streimikiene, G. Šivickas, The EU sustainable energy policy indicators framework, “Environment International” 2008, Vol. 34, Issue 8, pp. 1227-1240. 
in the European Union-What is needed to reach the 2020 targets?"30. These two articles relate to the EU climate and energy policy. The former article focuses on EU legal regulations in area of renewable sources of energy. The subject of study of the latter article is the EU growth strategy until the year 2020 (so called Europa 2020). This cluster is connected to the article of Andreas Pointvogl „Perceptions, realities, concession-What is driving the integration of European energy policies?". 31 This article is a liason component for the further two branches.

The first branch (lower to the left from position of A. Poinvogl) contains a monograph of Richard Youngs „Energy Security: Europe's New Foreign Policy Challenge", 32 an article of Aad Correljé et al. "Energy supply security and geopolitics: A European perspective" ${ }^{33}$ and an article of Dominique Finon et al. "Russian and European gas interdependence: Could contractual trade channel geopolitics?". ${ }^{4}$ The second branch is thematically similar to the previous branch. This includes the Communication from the Commission „An Energy Policy For Europe" 35 as well as a joint publication of Simon Pirani et al. „The Russo-Ukrainian gas dispute of January 2009: a comprehensive assessment" ${ }^{36}$ The book of S.Pirani et al. starts two new branches.

Considering thematic similarity of two larger branches it was necessary to identify the difference between the analysed academic publications that produced such a separation. To this end, it was decided to generate a detailed visualization of this subnetwork including those sources that was cited not less than 2 times (unlike Figure 2 that was generated from the sources cited more than 2 times). Additionally it was decided to change

30 C. Klessmann, A. Held, M. Rathmann, M. Ragwitz, Status and perspectives of renewable energy policy and deployment in the European Union -What is needed to reach the 2020 targets?, "Energy Policy" 2011, Vol. 39, Issue 12, pp. 7637-7657.

31 A. Pointvogl, Perceptions, realities, concession - What is driving the integration of European energy policies?, "Energy Policy" 2009, Vol. 37, Issue 12, pp. 5704-5716.

32 R. Youngs, The EU's Role in World Politics: a Retreat from Liberal Internationalism, Milton Park-Abingdon-Oxon [England] 2010.

33 A. Correlje, C. Van der Linde, Energy supply security and geopolitics: A European perspective, "Energy Policy" 2006, Vol. 34, Issue 5, pp. 532-543.

34 D. Finon, C. Locatelli, Russian and European gas interdependence: Could contractual trade channel geopolitics?, "Energy Policy" 2008, Vol. 36, Issue 1, pp. 423-442.

35 European Commission, An: Energy Policy For Europe, COM (2007) 1 Final, 10.01.2007.

36 S. Pirani, J. Stern, K. Yafimava, The Russo-Ukrainian Gas Dispute of January 2009: A Comprehensive Assessment, Oxford 2009. 
the perspective of the analysis by focusing on the citing articles connected to the network (n7, n15, n17, n38, n41, n50, n55, n56, n69, n79). The results are presented in Figure 3.

Figure 3. Detailed visualization of two branches connected by the article of A. Pointvogl

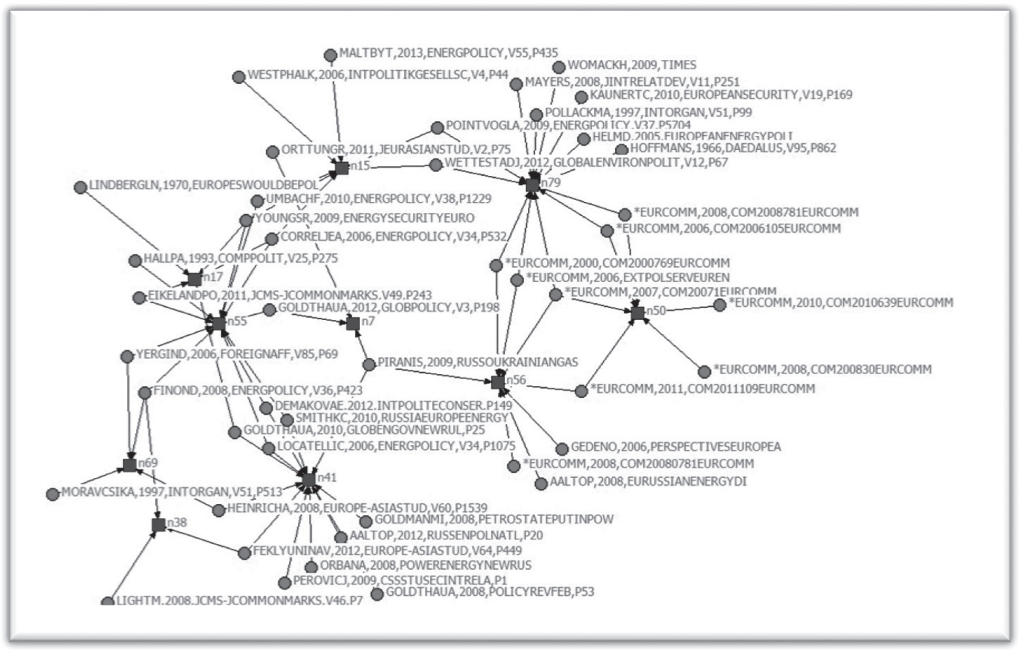

Source: Author's own data.

The detailed network visualization kept the main trends reflected in the Figure 2. However it introduced an adjustment. This adjustment was not contradictory to the connection trends shown in the Figure 2, yet it gave a better understanding of aforementioned division of the branches. In the same manner as in the Figure 2 the right branch connected the citing articles n50, n56 and n79. These were articles about the EU projects on carbon capture and storage (CCS), EU foreign energy policy illustrated by a EU - Russia dialogue, as well as EU energy policy. In addition to the thematic similarity these three articles were relatively well connected by their reference to the political and programming documents of the EC (nine of twenty such references were related to the publications of the EC).

The adjustment mentioned above affected positions $n 7$ and $n 41$. In the Figure 2 these positions created two separate branches. The subject of one of these articles was energy cooperation between EU and Russia from the 
institutional perspective. The subject of the other articles was the influence of developing shale gas industry on the EU - Russia relations. Figure 3 discovered a strong connection of these two articles with the left branch. The common component connecting two branches was still the book of S. Pirani et al.

The same as in the Figure 2 the left branch was formed by components $\mathrm{n} 15$, n17 and n55 (and, additionally, as mentioned above - by components $\mathrm{n} 7$ and $\mathrm{n} 41$ ). This branch connected articles related to EU energy policy in the global context as well as to the relations between EU and Russia in area of energy.

Additionally two components - n38 and n69 - created a short separate interconnected branch. The subject of these articles was relations between EU and Russia as well as the influence of Russia energy policy on the Turkey's accession process to the EU. Considering the topic of the articles as well as the nature of the journals where these articles were published ("International Politics" and "Journal of International Relations And Development") one can conclude that the EU energy policy was not the main subject of study but appeared as an independent variable in these articles.

To sum up, the visualization of the network based on previously made bibliographic analysis can provide a comprehensive insight to the scientific works on EU energy policy. It not only gives the possibility to determine remarkable scientists on the topic, but also visualises the belongingness of these authors to specific areas of studies within the broad scope of literature on EU energy policy.

\section{Conclusions}

Defining mainstream literature becomes a significant challenge for scientists considering the fast growing number of available academic literature on a specific topic. The paper analysed two methods of coping with this issue. The results of this analysis suggest several main findings.

First, the study has shown, that the application of "times-cited" and h-index as criteria lead to imprecise conclusions regarding the most frequently cited articles. Application of such time-dependent criteria produce problematic results for broad scientific disciplines with constant growth 
of academic publications. Presumably, the sustainability of $\mathrm{H}$-index may have minor importance in the disciplines with not so dynamic growth of scientific literature. Thus this finding supports the first hypothesis.

Second, the application of bibliometric approach produced sustainable results as it was based on data that does not changes through time. Hence, bibliometric method of defining mainstream literature successfully solves the shortcomings of the approach based on $\mathrm{H}$-index and times-cited criteria. As a result, the study has supported the second hypothesis that applying search criteria that are not time-dependent produce reliable results. In other words, bibliometric analysis of the same sample of 90 scientific articles that was used within this study will produce the same results at any time in the future.

Third, the study discovered some restrictions to generalization of conclusions that can be drawn from analysis of the list of the most influential publications generated by bibliometric approach. The top 27 of the most influential articles generated using bibliometric approach does not show the impact of the authors within specific area of study on EU energy policy. It also "hides" the full list of authors in case the academic publication was made in co-authorship. These conclusions proved that the list of the academic sources, although visually attractive and clear, is not the final stage of the research of a mainstream literature.

Finally, the visualization of a network of citing articles and cited references revealed the potential of bibliometric approach. It discovered the full map of mainstream academic literature including its divisions relatively to sub-topics of a study area. Thus the main objective of this research was comprehensively achieved.

Overall, the bibliometric approach to defining the mainstream literature presented in this paper, although requires advanced skills in Microsoft Excel, can be a useful tool for new scientists at initial stadium of a scientific project. It also provides relatively easy way to describe the state of the art in a certain subdiscipline for more experienced scientists. However in the long-term one should bear in mind that the method presents only mainstream literature. Using only mainstream literature in an academic work can restrict scientific creativity and even lead to a scientific deadlock in the later stadium of a research. 
Jans Kevišs-Petuško, $\mathrm{PhD}$ candidate

Embassy of Latvia in Warsaw

ul. Królowej Aldony 19, 03-928 Warszawa

jans.k-p@inbox.lv

\section{References}

Backlund S., Thollander P., Palm J., Ottosson M., Extending the Energy Efficiency Gap, "Energy Policy" 2012, Vol. 51.

Correlje A., Van der Linde C., Energy supply security and geopolitics: A European perspective, "Energy Policy" 2006, Vol. 34, Issue 5.

Del Río P., The dynamic efficiency offeed-in tariffs: The impact of different design elements, "Energy Policy" 2012, Vol. 41.

European Commission, Action Plan for Energy Efficiency - Realising the Potential, http://eur-lex.europa.eu/legal-content/EN/TXT/HTML/? uri=CELEX:52006DC0545\&from=EN.

European Commission, An: Energy Policy For Europe, COM (2007) 1 Final, 10.01.2007.

Fankhauser S., Hepburn C., Park J., Combining multiple climate policy instruments: how not to do it, "Climate Change Economics" 2010, Vol. 1, Issue 3.

Exadaktylos T., Radaelli C.M., Research Design in European Studies: The Case of Europeanization, "Journal of Common Market Studies" 2009, Vol. 47, Issue 3.

Finon D., Locatelli C., Russian and European gas interdependence: Could contractual trade channel geopolitics?, "Energy Policy" 2008, Vol. 36, Issue 1.

Fleiter T., Worrell E., Eichhammer W., Barriers to Energy Efficiency in Industrial Bottom-up Energy Demand Models - a Review, "Renewable and Sustainable Energy Reviews" 2011, Vol. 15, Issue 6.

Haas R., Panzer C., Resch G., Ragwitz M., Reece G., Held A., A Historical Review of Promotion Strategies for Electricity from Renewable Energy Sources in EU Countries, "Renewable and Sustainable Energy Reviews" 2011, Vol. 15, Issue 2. 
Haas R., Resch G., Panzer C., Busch S., Ragwitz M., Held A., Efficiency and effectiveness of promotion systems for electricity generation from renewable energy sources - Lessons from EU countries, "Energy" 2011, Vol. 36, Issue 4.

Hirsch J.E., An Index to Quantify an Individual's Scientific Research Output, "Proceedings of the National Academy of Sciences of the United States of America" 2005, Vol. 102, Issue 46.

Jacobsson S., Bergek A., Finon D., Lauber V., Mitchell C., Toke D., Verbruggen A., EU renewable energy support policy: Faith or facts?, "Energy Policy" 2009, Vol. 37, Issue 6.

Kitzing L., Mitchell C., Morthorst P.E., Renewable Energy Policies in Europe: Converging or Diverging, "Energy Policy" 2012, Vol. 51.

Klessmann C., Held A., Rathmann M., Ragwitz M., Status and perspectives of renewable energy policy and deployment in the European Union What is needed to reach the 2020 targets? "Energy Policy" 2011, Vol. 39, Issue 12.

Leyedesdorff L., BibJourn.exe for Cocitation Analysis of Journal Names in References, http://www.leydesdorff.net/software/bibjourn/.

Menanteau P., Finon D., Lamy M.-L., Prices versus quantities: choosing policies for promoting the development of renewable energy, "Energy Policy" 2003, Vol. 31, Issue 8.

Mitchell C., Bauknecht D., Connor P.M., Effectiveness Through Risk Reduction: A Comparison of the Renewable Obligation in England and Wales and the Feed-in System in Germany, "Energy Policy" 2006, Vol. 34, Issue 3.

Pirani S., Stern J., Yafimava K., The Russo-Ukrainian Gas Dispute of January 2009: A Comprehensive Assessment, Oxford 2009.

Pointvogl A., Perceptions, realities, concession - What is driving the integration of European energy policies?, "Energy Policy" 2009, Vol. 37, Issue 12.

Rohdin P., Thollander P., Solding P., Barriers to and Drivers for Energy Efficiency in the Swedish Foundry Industry, "Energy Policy" 2007, Vol. 35, Issue 1.

Sorrell S., Schleich J., Scott S., O’Malley E., Trace F., Boede U., Ostertag K., Radgen P., Reducing barriers to energy efficiency in public and private 
organizations, [in:] Science and Policy Technology Research (SPRU), Sussex 2000.

Streimikiene D., Šivickas G., The EU sustainable energy policy indicators framework, "Environment International" 2008, Vol. 34, Issue 8.

Thollander P., Danestig M., Rohdin P., Energy Policies for Increased Industrial Energy Efficiency: Evaluation of a Local Energy Programme for Manufacturing SMEs, "Energy Policy” 2007, Vol. 25, Issue 11.

Thollander P., Ottosson M., An Energy Efficient Swedish Pulp and Paper Industry - Exploring Barriers to and Driving Forces for Cost-effective Energy Efficiency Investments, "Energy Efficiency" 2008, Vol. 1, Issue 1. Thollander P., Ottosson M., Energy Management Practices in Swedish Energy-intensive Industries, "Journal of Cleaner Production" 2010, Vol. 18 Issue 12.

Thollander P., Svensson I.-L., Trygg L., Analyzing Variables for District Heating Collaborations Between Energy Utilities and Industries, "Energy" 2010, Vol. 35, Issue 9.

Tilman D., Socolow R., Foley J.A., Hill J., Larson E., Lynd L., Pacala S. et al., Biofuels: steer clear of degraded land response, "Science" 2009, Vol. 325, Issue 5938.

Tinbergen J., On the Theory of Economic Policy, Amsterdam 1952.

Youngs R., The EU's Role in World Politics: a Retreat from Liberal Internationalism, Milton Park-Abingdon-Oxon [England] 2010.

\title{
Defining mainstream literature: the case of energy policy of the European Union
}

\begin{abstract}
Several approaches are available to define the mainstream academic literature in a certain subdiscipline. However the sustainability of the findings of those searches is still an open issue. The paper addresses this problem by examining two approaches to defining the mainstream literature on a certain topic. In the first case, it verifies the approach of creation of the list of the most influential scientific publications using the "times-cited" and $\mathrm{H}$-index as two of the main criteria. In the second case, the study applies a bibliometric approach by examining 90 academic articles on energy policy of the European Union published in 2013-2015. The
\end{abstract}


study shows that former approach may lead to unsustainable search results as they are dependent on time when the search was completed. The search using bibliometric approach ensures sustainable results as they are not time-dependent. It produces the list of the most influential 28 academic sources on the topic that will not change through time if one applies the same sample of articles. The both approaches use the ISI Web of Science database. But as the latter uses the older version of the database, the search is limited to the articles published not later than 2015. The both approaches examine articles in English only. Therefore the paper provides general reflections on objectivity of such findings in a broader context of the study of energy policy of the EU.

Keywords: energy policy of the EU, bibliometric approach, $\mathrm{H}$-index, times-cited, europeanization

\section{Опредемение литературы основного направмения: пример энергетической помитики Европейского Союза}

\section{Абстракт}

Учёные используют несколько способов поиска научной митературы основного направления в рамках определённых подотраслей науки. ОАнако наАёжность результатов таких поисков может быть подвергнуто сомнению. Эта статья пробует решить эту проблему, применяя Ава подхода к поиску митературы основного направления на определённую тему. В первом случае был проверен подхоА к поиску наиболее влиятельных научных публикаций, используя главными критериями такие показатели как сумма цитирования и индекс Хирша. Во втором же случае был применён библиометрический поАхоА, анализируя 90 научных статей на тему энергетической политики Европейского Союза, опубликованных в 2013-2015 гг. Результаты анализа показали, что первый подход предоставцяет ненадёжные результаты, потому что они зависят от времени, когАа бым произвеАён поиск. В свою очереАь, библиометрический поАхоА обеспечивает наАёжные результаты, ввиАу того, что они не зависят от времени. Благодаря использованию библиометрического подхоАа, был получен список 28 самых вАиятельных научных источников на тему энергетической политики ЕС в 2013-2015 гг. Оба метода используют базу данных ISI Web of Science. В исследовании были использованы статьи только на английском языке. Аополнительно, статья знакомит с потенциалом библиометрического подхоАа, а также вкцючает 
в себя общее размышление об объективности полученных Аанных в более широком контексте исслеАований на тему энергетической политики ЕС.

Кмючевые слова: энергетическая помитика EC, индекс Хирша, библиометрический поАхоА, сумма цитирований, европеизация 